\title{
Acid-base balance in ruminating calves given sodium hydroxide-treated straw
}

\author{
BY SØREN WAMBERG ${ }^{1}$ AND KNUD ENGEL ${ }^{2}$ \\ Departments of ${ }^{1}$ Physiology and ${ }^{2}$ Clinical Chemistry, Odense University Medical School, \\ DK-5230 Odense $M$, Denmark
}

AND PETER STIGSEN*

Department of Animal Physiology and Chemistry, National Institute of Animal Science,
DK-1958 Copenhagen, Denmark

(Received 29 November 1984 - Accepted 4 June 1985)

1. Studies of whole-body balances of non-metabolizable base (NB) and several minerals, and of relevant acid-base quantities in blood and urine, were carried out in two 6-month-old ruminating Holstein $\times$ Friesian bull calves fed on fixed rations containing $500 \mathrm{~g}$ barley straw $/ \mathrm{kg}$ diet (group A) to examine the quantitatively important components of the balance of NB and determine the rates of mineral and NB retention associated with normal body growth.

2. Parallel balance studies were conducted in six other bull calves given fixed rations containing $500 \mathrm{~g}$ alkali-treated barley straw $/ \mathrm{kg}$ diet to evaluate the effects of long-term alkali-straw feeding on the rates of body growth and skeletal mineral and NB deposition and the renal control of extracellular electrolyte and acid-base status. The straw component was treated either with $50 \mathrm{~g}$ sodium hydroxide/kg dry matter (DM) (group B; two calves), or with $50 \mathrm{~g}$ or $100 \mathrm{~g} \mathrm{NaOH} / \mathrm{kg} \mathrm{DM}$ and subsequently neutralized with hydrochloric acid (groups $\mathrm{C}$ and $\mathrm{D}$; two calves per group). In all groups the animals were given free access to tap water.

3. Throughout the total $105 \mathrm{~d}$ experiment, all animals remained healthy and gained weight. Normal body growth (group A) was associated with a positive balance of NB (1-2 mmol/ $\mathrm{kg}$ live weight (LW) per d) due to continuing deposition of dietary NB in 'new tissue', largely in the developing skeleton.

4. During $105 \mathrm{~d}$ alkali-straw feeding, the animals showed a remarkable ability to cope with dietary loads of $\mathrm{NaOH}$ or sodium chloride, up to about $30 \mathrm{mmol} / \mathrm{kg} \mathrm{LW}$ per d, without any significant disturbance of extracellular acid-base and electrolyte status or body growth rate. The surplus mineral and NB loads were absorbed and subsequently excreted in an increased volume of urine. Rates of mineral and NB retention were not significantly different from the reference values of group A and remained within the range of values reported from similar studies. In all groups, maintenance of normal whole blood and plasma acid-base and electrolyte status was accounted for by efficient renal control of the composition of the extracellular fluid compartment.

In the past two decades the development of new techniques for industrial production of alkali-treated roughages has encouraged a number of animal nutritionists to study the effects of alkali-straw feeding on dietary intake, body growth, rumen microbial activity, in vivo digestibility, etc. (Saxena et al. 1971; Oloade \& Mowat, 1975; Jackson, 1977; Friis Kristensen et al. 1978; Coombe et al. 1979; Sriskandarajah \& Kellaway, 1984). Apparently, however, only limited information on the effects of alkali-straw feeding on acid-base metabolism and mineral turnover in the ruminant is available (Voigt \& Piatkowski, 1974; Friis Kristensen et al. 1978).

In the present study, investigations of mineral and acid-base metabolism were carried out in two 6-month-old ruminating Holstein $\times$ Friesian bull calves, fed on a basic ration containing $500 \mathrm{~g}$ barley straw $/ \mathrm{kg}$ diet, in order to determine quantitatively the components of the whole-body balance of (titratable) non-metabolizable base (NB), and to determine the rates of mineral and NB retention associated with normal body growth. Parallel series of balance studies were conducted in two bull calves subjected to long-term feeding on alkali-straw rations and in four calves given alkali-straw neutralized with hydrochloric acid

* Present address: Flexplan Agro Projects A/S, DK-2970 Hørsholm, Denmark. 
Table 1. Age, live weight, and rates of weight gain and dietary and water intake

(Mean values and standard errors ( $4 \mathrm{df}$ ) for two calves per group studied during periods 1-6)*

\begin{tabular}{|c|c|c|c|c|c|c|c|c|c|c|c|c|}
\hline \multirow[b]{3}{*}{ Group } & \multirow[b]{3}{*}{ Ration $\dagger$} & \multirow{3}{*}{$\begin{array}{l}\text { Age on } \\
\text { arrival } \\
\text { (d) }\end{array}$} & \multicolumn{4}{|c|}{ Live wt } & \multicolumn{4}{|c|}{ Dietary intake } & & \\
\hline & & & \multirow{2}{*}{$\begin{array}{c}\text { Initial } \\
(\mathrm{kg})\end{array}$} & \multirow{2}{*}{$\begin{array}{c}\text { Final } \\
(\mathrm{kg})\end{array}$} & \multicolumn{2}{|c|}{$\begin{array}{l}\text { Gain } \\
(\mathrm{kg} / \mathrm{d})\end{array}$} & \multicolumn{2}{|c|}{$\begin{array}{l}\text { Dry matter } \\
(\mathrm{kg} / \mathrm{d})\end{array}$} & \multicolumn{2}{|c|}{$\begin{array}{l}\text { Gross energy } \\
(\mathrm{MJ} / \mathrm{d})\end{array}$} & \multicolumn{2}{|c|}{$\begin{array}{l}\text { Water intake } \\
\text { (I/d) }\end{array}$} \\
\hline & & & & & Mean & $\mathrm{SE}$ & Mean & $\mathrm{SE}$ & Mean & $\mathrm{SE}$ & Mean & $\mathrm{SE}$ \\
\hline A & US & 155 & 214.0 & $269 \cdot 0$ & $0.71)$ & \multirow{4}{*}{0.09} & $5.52)$ & \multirow{4}{*}{$0 \cdot 30$} & $102 \cdot 1$ & \multirow{4}{*}{5.4.} & 21.8 & \multirow{4}{*}{$2 \cdot 27$} \\
\hline B & AS & 149 & $216 \cdot 5$ & $278 \cdot 0$ & 0.80 & & $5 \cdot 92$ & & 106.9 & & $36 \cdot 7$ & \\
\hline $\mathrm{C}$ & NS50 & 146 & 206.0 & $268 \cdot 0$ & 0.82 & & $5 \cdot 68$ & & 101.9 & & $26 \cdot 6$ & \\
\hline $\mathrm{D}$ & NS100 & 141 & $205 \cdot 5$ & 258.0 & 0.68 & & $5 \cdot 52$ & & 97.4 & & $26 \cdot 2$ & \\
\hline
\end{tabular}

US, untreated barley straw; AS, alkali-treated barley straw; NS50, NS100, neutralized barley straw.

* For details, see Fig. 1 (p. 661).

$\dagger$ For details, see Tables 2 and 3 (p. 657).

in order to examine the effects of excessive dietary loading with sodium hydroxide (i.e. NB) or sodium chloride on (1) rates of body growth and mineral and NB retention, (2) several acid-base quantities in blood and urine, and (3) renal control of extracellular acid-base and electrolyte status. The results were compared with the reference values obtained in the two animals given untreated barley straw.

\section{EXPERIMENT A L}

\section{Animals and management}

Eight Holstein $\times$ Friesian bull calves were raised on milk-substitute, concentrates including vitamin and mineral supplements, and hay until approximately 6 months of age. On arrival at the National Institute of Animal Science, the animals were treated against parasites with Thibenzole vet. (MSD, Rahway, NJ, USA; $100 \mathrm{mg} / \mathrm{g}$ ) and, following premedication with Rompun vet. (Bayer Chemie, Leverkusen, FRG; $20 \mathrm{mg} / \mathrm{ml}$ ) and application of anaesthetic by local injection of lidocaine (DAK, Copenhagen; $10 \mathrm{mg} / \mathrm{ml}$ ), the calves were castrated and the right carotid artery exteriorized to a cervical skin loop for repetitive sampling of arterial blood. On recovery, the animals were randomly allocated to four groups (A-D) of two calves (see Table 1) and confined to individual metabolism crates fitted with a rubber-coated floor with a receptacle below and a box behind for quantitative collection of urine and faeces. Throughout the study each group was fed on a composite ration as described later and, following 3 weeks of adaptation, the animals were studied for six consecutive balance periods, each consisting of a $7 \mathrm{~d}$ conditioning period followed by a $7 \mathrm{~d}$ collection period (see Fig. 1, p. 661). Mean live weight (LW) and rates of weight gain were obtained by weighing the animals immediately before and after each collection period (Table 1). For further details of the techniques employed, see Thorbek (1980) and Wamberg et al. $(1976 a, b)$.

\section{Dietary preparations}

Throughout the study the calves were given weighed portions of the experimental rations specified in Table 2 , daily at 07.00 and 15.00 hours. The total amount of feed offered in each collection period was equal to the ad lib. intake of the control animals of group A during the preceding 7-d conditioning period. All animals were given free access to tap water. 
Table 2. Composition of experimental rations $(\mathrm{g} / \mathrm{kg})$

\begin{tabular}{|c|c|c|c|c|}
\hline \multirow[b]{2}{*}{ Feed component } & \multicolumn{4}{|c|}{ Ration } \\
\hline & US & AS & NS50 & NS 100 \\
\hline Untreated barley straw & 500 & - & - & - \\
\hline $\begin{array}{l}\text { Treated barley straw } \\
\text { (50 g sodium hydroxide/kg DM) }\end{array}$ & - & 500 & - & 一 \\
\hline $\begin{array}{l}\text { Treated straw } \\
(50 \mathrm{~g} \mathrm{NaOH} / \mathrm{kg} \mathrm{DM}) \\
\text { neutralized with hydrochloric acid }\end{array}$ & - & - & 500 & - \\
\hline $\begin{array}{l}\text { Treated straw } \\
(100 \mathrm{~g} \mathrm{NaOH} / \mathrm{kg} \mathrm{DM}) \\
\text { neutralized with hydrochloric acid }\end{array}$ & - & - & - & 500 \\
\hline Barley, rolled & 120 & 120 & 120 & 120 \\
\hline Wheat bran & 60 & 60 & 60 & 60 \\
\hline Molasses & 70 & 70 & 70 & 70 \\
\hline Soya-bean meal & 170 & 170 & 170 & 170 \\
\hline Linseed cake & 40 & 40 & 40 & 40 \\
\hline Linseed & 20 & 20 & 20 & 20 \\
\hline Mineral-vitamin mixture* & 20 & 20 & 20 & 20 \\
\hline
\end{tabular}

DM, dry matter.

* Minerals (g/kg): $\mathrm{CaHPO}_{4} \cdot 2 \mathrm{H}_{2} \mathrm{O} 388 \cdot 5, \mathrm{CaCO}_{3} 400, \mathrm{NaCl} 180, \mathrm{FeSO}_{4} \cdot 7 \mathrm{H}_{2} \mathrm{O} 10, \mathrm{MnO}, 5, \mathrm{CuSO}_{4} .5 \mathrm{H}_{2} \mathrm{O} 9$, $\mathrm{CoSO}_{4} .7 \mathrm{H}_{2} \mathrm{O} 0 \cdot 4, \mathrm{ZnO} 7 ; \mathrm{Ca}\left(\mathrm{IO}_{3}\right)_{2} 0 \cdot 1$. Vitamins $(\mu \mathrm{g} / \mathrm{g})$ : retinol 120, ergocalciferol 3, $\alpha$-tocopherol 100.

Table 3. Average chemical composition of experimental rations

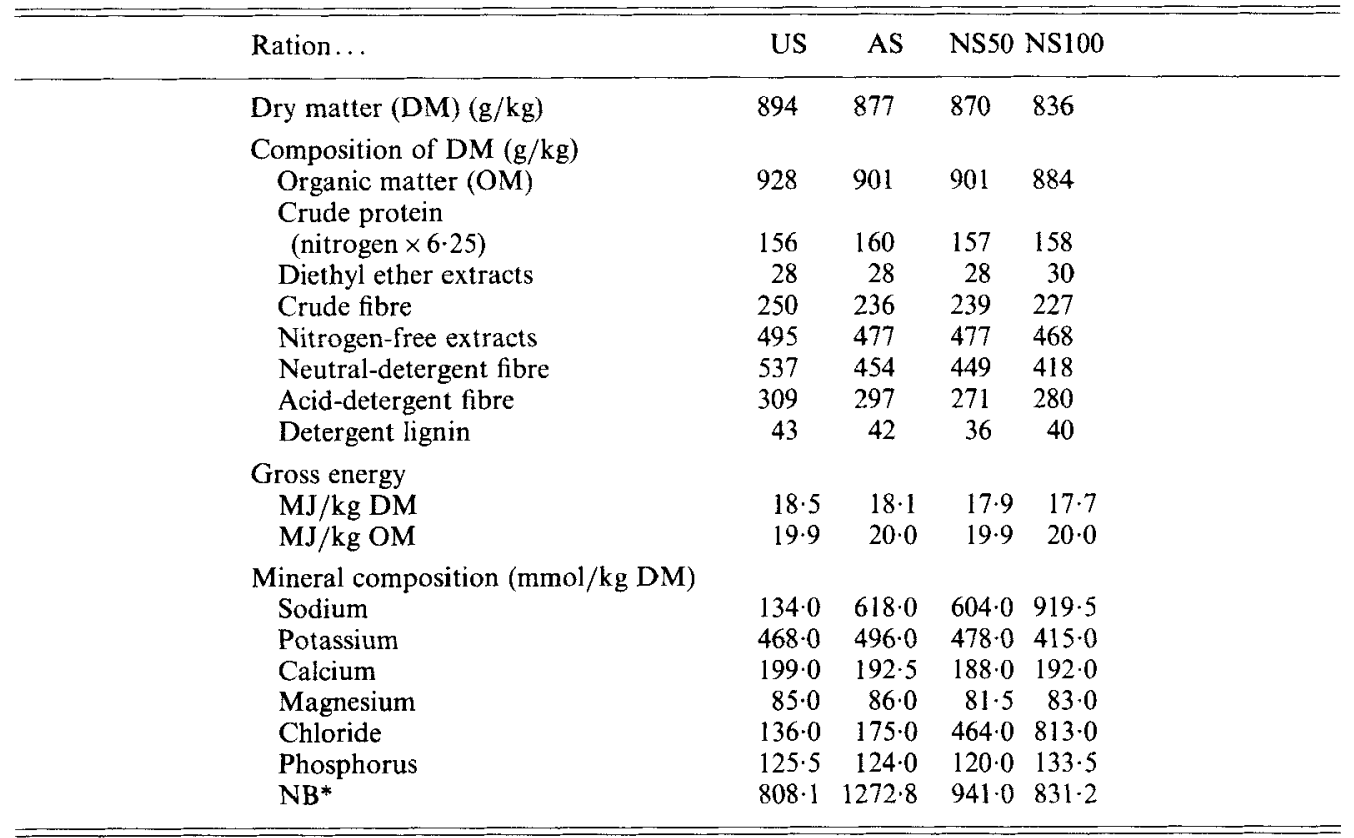

NB, non-metabolizable base.

* Calculated according to eqn (2) (p. 659). 
Details of the chemical composition of the ration for each experimental group are given in Table 3. All feed mixtures contained $500 \mathrm{~g}$ barley straw $/ \mathrm{kg}$ diet and were pressed into 14-mm cobs. The chopped barley straw was either untreated (ration US) or spray-treated with $8 \mathrm{M}-\mathrm{NaOH}$ corresponding to approximately $50 \mathrm{~g} \mathrm{NaOH} / \mathrm{kg}$ dry matter (DM) (rations AS and NS50) or $100 \mathrm{~g} \mathrm{NaOH} / \mathrm{kg} \mathrm{DM}$ (ration NS100). Before the final processing step, residual amounts of $\mathrm{NaOH}$ in rations NS50 and NS100 were neutralized with $\mathrm{HCl}$ (Table 3). For further details of the alkali-spray technique, developed at the Biotechnical Institute, Kolding, Denmark, see Rexen \& Vestergaard Thomsen (1976) and Friis Kristensen et al. (1978).

\section{Sampling}

Diets. Dietary intake was measured by weighing out the daily rations and correcting for any food residue. For each balance period, portions were taken for chemical analysis.

Water. The daily water intake of each animal was measured by means of a calibrated water meter.

Faeces and urine. Each day faeces and urine were collected quantitatively at 08.00, 12.00 and 16.00 hours and thoroughly mixed. Samples of approximately $10 \%$ of the faeces and $5 \%$ of the urine (with a few crystals of mercuric iodide) were frozen for subsequent analysis.

Blood. During each balance period, arterial (carotid) and venous (jugular) blood samples were drawn anaerobically in heparinized glass syringes. However, due to anxiety and excitement of the animals, this sampling procedure failed to give reliable blood acid-base values, and during the final collection period (period 6) blood was obtained by means of indwelling carotid catheters inserted under local anaesthesia on day 92 (see Table 6, p. 664).

\section{Sample preparation}

Diets. Samples of the composite feed cobs were ground, dried to constant weight at $100^{\circ}$ and boiled in $0.7 \mathrm{M}$-nitric acid for $1 \mathrm{~h}$ under reflux. After cooling, samples of the filtrate were frozen for subsequent analysis.

Faeces. Homogenized samples of faeces were freeze-dried and weighed portions were boiled in $0.7 \mathrm{M}-\mathrm{HNO}_{3}$, filtered and stored at $-20^{\circ}$ until analysed.

Urine. Thawed, filtered specimens of urine were analysed within $6 \mathrm{~h}$ or refrozen.

Blood. The acid-base status of arterial blood was determined within $2 \mathrm{~h}$ of sampling. Residual blood was centrifuged and the plasma frozen for mineral analyses.

\section{Analytical methods}

Dietary DM composition and gross energy were determined as previously described (Thorbek, 1980). Concentrations of sodium, potassium, calcium, magnesium, chloride and total phosphorus in tap water and in the diet, faeces, urine and plasma, as well as concentrations of sulphate in urine, were measured by methods described previously (Wamberg et al. 1976a, b). Arterial blood acid-base status was determined by the equilibration technique (Siggaard-Andersen, 1974) and urinary (titratable) non-carbonic acid (NCA) and ammonia were measured by potentiometric titration at $37^{\circ}$ and a carbon dioxide pressure of $0 \mathrm{mmHg}$ as described by Jørgensen (1957). All measurements were performed in duplicate; estimates of analytical accuracy were obtained by analysis of an aqueous standard solution with each batch of samples (Wamberg et al. 1976a) showing a coefficient of variation of less than $2.4 \%$ for any component.

\section{Statistical analysis of results}

All values are presented as means with their pooled standard errors.

In all cases no significant interaction between balance periods and dietary groups was 
found $(P>0.05)$. The standard error for comparison of dietary groups was based on the variation between calves within groups ( $4 \mathrm{df}$ ) and that for balance-period comparisons was based on the interaction between periods and calves within dietary groups $(20 \mathrm{df})$. In the case of blood acid-base values (Table 6, p. 664) the same analysis was applied, except that balance periods were replaced by time of blood sampling ( $3 \mathrm{df})$. The computations were performed by means of the GLIM system developed by Baker \& Nelder (1978).

\section{Calculations}

In traditional acid-base physiology, investigations are usually limited to measurements of carbonic acid (CA) and NCA in blood, plasma, urine, etc. (Hills, 1973; Dobson, 1980). However, in studies of nutritional and system-physiological aspects of acid-base metabolism it is necessary to distinguish between two kinds of NCA (or base), i.e. metabolizable organic acid (MA) subject to metabolic control, and non-metabolizable acid (NA) or base (NB) subject to renal control and elimination (Kildeberg \& Winters, 1978; Kildeberg, 1981). Thus, for any system the concentration $(c)$ of NCA is

$$
c \mathrm{NCA}=c \mathrm{MA}+c \mathrm{NA}=c \mathrm{MA}-c \mathrm{NB} .
$$

In the organism, metabolic processes invariably result in positive concentrations of CA and MA in cell water and plasma and, in order to maintain (normal) extracellular $\mathrm{pH}$ values slightly above the chemical point of neutrality $\left(\mathrm{pH} 7.00\right.$ at $\left.25^{\circ}\right)$, the organism is dependent on an external source of NB. In the diet, the stoichiometric content of NB is to some extent neutralized ('titrated') by MA. However, by oxidative degradation of absorbed MA absorbed NB is reconstituted and thus available for processes of growth and homeostasis.

In the present study, concentrations of $\mathrm{NB}$ in the diet, faeces, urine and plasma were calculated from measured concentrations of non-metabolizable ions multiplied by their average net charge at $\mathrm{pH} 7.40$ (Wamberg et al. 1976b; Kildeberg, 1981, 1983),

$$
c \mathrm{NB}=c \mathrm{Na}^{+}+c \mathrm{~K}^{+}+2 c \mathrm{Ca}^{2+}+2 c \mathrm{Mg}^{2+}-c \mathrm{Cl}^{-}-1 \cdot 8 c \mathrm{P} \mathrm{P}-2 c \mathrm{SO}_{4}{ }^{2-},
$$

where $\mathrm{tP}$ is total $\mathrm{P}$. In the case of the diet, faeces and plasma the $\mathrm{SO}_{4}{ }^{2-}$ was ignored (see Table 4, p. 662).

It follows that $c \mathrm{NB}$ represents the sum of titratable values of stoichiometrical concentrations of non-metabolizable Brønsted bases $\left(\mathrm{NaOH}, \mathrm{KOH}, \mathrm{Ca}(\mathrm{OH})_{2}, \mathrm{Mg}(\mathrm{OH})_{2}\right)$ minus that of non-metabolizable Brønsted acids $\left(\mathrm{HCl}, \mathrm{H}_{3} \mathrm{PO}_{4}, \mathrm{H}_{2} \mathrm{SO}_{4}\right)$ in the sample.

The concentration of NB may also be obtained by direct titration, and in the case of urine the principle of electroneutrality requires that

$$
c \mathrm{NB}(\mathrm{U})=c \mathrm{MA}_{\mathrm{g}}(\mathrm{U})-\left[c \mathrm{NCA}(\mathrm{U})+c \mathrm{NH}_{4}^{+}(\mathrm{U})\right],
$$

where $c \mathrm{MA}_{\mathrm{g}}(\mathrm{U})$ is the concentration in urine of MA lost by the process of glomerular filtration (Engel \& Kildeberg, 1977; Kildeberg, 1981). For plasma, the following applies

$$
c \mathrm{NB}(\mathrm{P})=c \mathrm{MA}(\mathrm{P})-c \mathrm{NCA}(\mathrm{P})=c \mathrm{MA}(\mathrm{P})+c \mathrm{BE}(\mathrm{P})+K,
$$

where $c \mathrm{BE}(\mathrm{P})$ is the 'base excess' of plasma (Siggaard-Andersen, 1974) and $K$ is a constant, approximately $24 \mathrm{mmol} / 1$. Thus, by measuring $c \mathrm{NB}$ values according to eqn (2), $c \mathrm{NCA}(\mathrm{U})$ $+c \mathrm{NH}_{4}{ }^{+}(\mathrm{U})$ according to Jørgensen (1957), and $c \mathrm{BE}(\mathrm{P})$ according to Siggaard-Andersen (1974), values of $c \mathrm{MA}_{\mathrm{g}}(\mathrm{U})$ and $c \mathrm{MA}(\mathrm{P})$ can be obtained by subtraction.

\section{Balance of $N B$}

In animal physiology, the balance technique is widely used in studies of changes in whole-body content of various substances. By definition, the whole-body balance of a given substance is the difference between the mean rate of gain by all sources (input) and the mean rate 
of loss by all routes (output). The distinction between input and output is mathematically arbitrary, depending on a sign convention, and may therefore be based on considerations of physiological control mechanisms. In the case of acid-base metabolism, constancy of the concentration of NB in extracellular fluid is achieved by renal mechanisms (Kildeberg, 1981; Wamberg et al. 1983). Accordingly, in studies of the balance of NB the output is by definition the mean rate of renal NB excretion, the input being the mean rate of gain of NB by all extra-renal processes such as gastrointestinal absorption, endogenous production, and distribution between body compartments (see Fig. 2, p. 665). Because the mean rate of endogenous production of $\mathrm{H}_{2} \mathrm{SO}_{4}$ cannot be assessed independently of the rate of renal excretion, the assumption of a zero sulphate balance is requisite to the calculation of the balance of NB (Kildeberg \& Winters, 1978; Kildeberg, 1981). In deriving meaningful balance values it is of course essential that the same object of measurement be applied to the various sources of gain and loss. In the case of the balance $(b)$ of NB $(b \mathrm{NB})$, gain of acid corresponds to loss of base and vice versa:

$$
b \mathrm{NB}=\dot{n} \mathrm{NB}(\mathrm{i})-\dot{n} \mathrm{NB}(\mathrm{o})=\dot{n} \mathrm{NB}(\mathrm{d})-\dot{n} \mathrm{NB}(\mathrm{f})+\dot{n} \mathrm{NB}(\mathrm{e})-\dot{n} \mathrm{NB}(\mathrm{u}),
$$

where $\dot{n} \mathrm{NB}$ denotes mean substance rate of NB (mmol/kg LW per d) and the process specifications in parentheses denote input (i), output (o), dietary intake (d), faecal loss (f), endogenous production (e) and renal excretion (u). As explained previously, the mean rate of endogenous NA production $(-\dot{n} \mathrm{NB}(\mathrm{e}))$ is taken to be equal to twice the mean rate of urinary sulphate excretion $\left(\dot{n} \mathrm{SO}_{4}{ }^{2-}(\mathrm{u})\right)$ (see Table 4, p. 662 and Fig. 2, p. 665).

\section{RESULTS}

Body growth

In all groups the animals remained healthy throughout the study and, except for the final balance period (period 6), rates of weight gain were not significantly different. According to the values in Table 1, mean rates of dietary DM intake and feed conversion ratios $(\mathrm{MJ} / \mathrm{kg}$ weight gain) were rather similar in all groups and comparable to the results obtained by Thorbek (1980).

\section{Water metabolism}

In group $\mathrm{B}$, dietary loading with extra $\mathrm{Na}$ and $\mathrm{NB}$ resulted in a highly significant increase (from 21.8 to $36.7 \mathrm{l} / \mathrm{d}$ ) in the mean rate of water intake and a similar increase (from 6.2 to $19.71 / \mathrm{d}$ ) in mean daily urinary volume. By contrast, in response to dietary $\mathrm{NaCl}$ loading, the observed increase in daily water intake by the animals of groups $C$ and $D(4.8$ and $4.41 / d$ respectively) was distinctly lower. At the same time the mean daily volume of urine rose by $5 \cdot 2$ and $10.31 / \mathrm{d}$ in groups $\mathrm{C}$ and $\mathrm{D}$ respectively, apparently due in part to a shift in water excretion from faeces to urine (see p. 664).

\section{Mineral metabolism}

Table 4 shows mean rates of dietary intake and faecal and urinary excretion as well as mean rates of absorption and retention of the six minerals studied. Means of intra-individual whole-body balances of NB, calculated according to eqns (2) and (5), are presented in Table 4 and Fig. 2 (pp. 662 and 665); and pertinent urinary acid-base and electrolyte values are given in Table 5. The results show that in groups B and C the surplus loads of dietary Na and NB were almost quantitatively absorbed from the gastrointestinal tract along with $\mathrm{K}, \mathrm{Cl}$ and additional water, and subsequently excreted in the urine. In group $\mathrm{D}$, a similar response to dietary $\mathrm{NaCl}$ loading was observed. Furthermore, in all groups the rates of turnover of $\mathrm{Ca}, \mathrm{Mg}$ and total-P followed the same pattern and remained not significantly different 


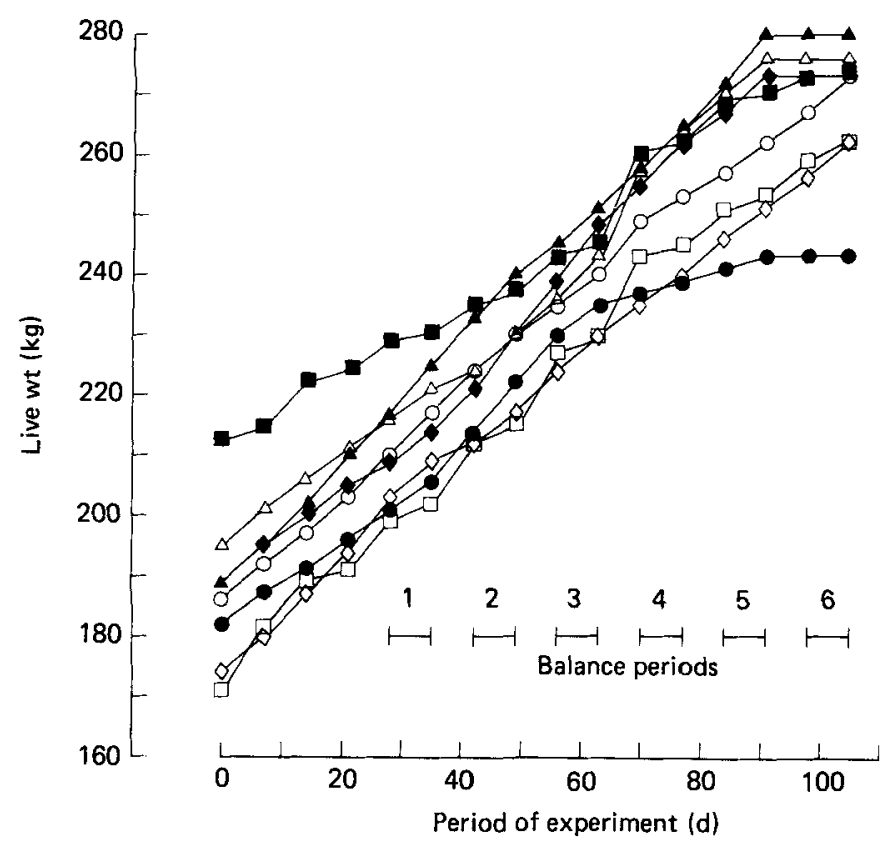

Fig. 1. Individual live-weight gains of ruminating calves in relation to balance periods 1-6. Group A (untreated barley straw) ( $\square$ ), group B (alkali-treated barley straw) $(\Delta \Delta)$ ), group C (neutralized barley straw, ration NS50) $(\diamond)$ ), group D (neutralized barley straw, ration NS100) $(0 \bigcirc)$ ). For details of rations, see Tables 2 and 3 .

$(P>0.05)$. However, an unexpected but statistically significant difference between balance periods for $\mathrm{K}, \mathrm{Ca}, \mathrm{P}$ and NB was found, apparently due to dietary batch variations.

\section{Acid-base metabolism}

During alkali-straw feeding the animals of group $\mathrm{B}$ ingested and absorbed considerable amounts of dietary Na and NB, while faecal NB excretion remained not significantly different $(P>0.05)$ from the control value of group A (Table 4). At the same time the estimated average rate of endogenous $\mathrm{H}_{2} \mathrm{SO}_{4}$ production rose slightly and, as a result, the animals of groups B and C faced a net extra-renal load of NB (input) averaging $20 \cdot 1$ and $12.5 \mathrm{mmol} / \mathrm{kg} \mathrm{LW}$ per d respectively (Fig. 2). In both groups, however, the increase in NB input was closely matched by a corresponding rise in the mean rate of renal NB excretion (11.2 and $4.1 \mathrm{mmol} / \mathrm{kg} \mathrm{LW}$ per d respectively), accounted for by increased volumes of urine with moderately elevated concentrations of sodium bicarbonate (negative values of $c \mathrm{NCA}(\mathrm{U})$ ) but low concentrations of (filtered) MA (Table 5). In all groups, irrespective of the magnitude of dietary NB loading, normal body growth was associated with a positive balance of NB of about 1-2 mmol/kg per d (Table 4 and Fig. 2).

\section{Blood acid-base and electrolyte status}

In Table 6, mean arterial blood and plasma acid-base values obtained during days 4 and 5 of the final collection period are presented. It appears that in spite of the magnitude of alkali loading, arterial blood acid-base status of the animals of groups B, C and D remained within the normal range (Dobson, 1980). Similarly, the plasma concentrations of BE, NB and MA obtained in these groups were not significantly different from those of group A 


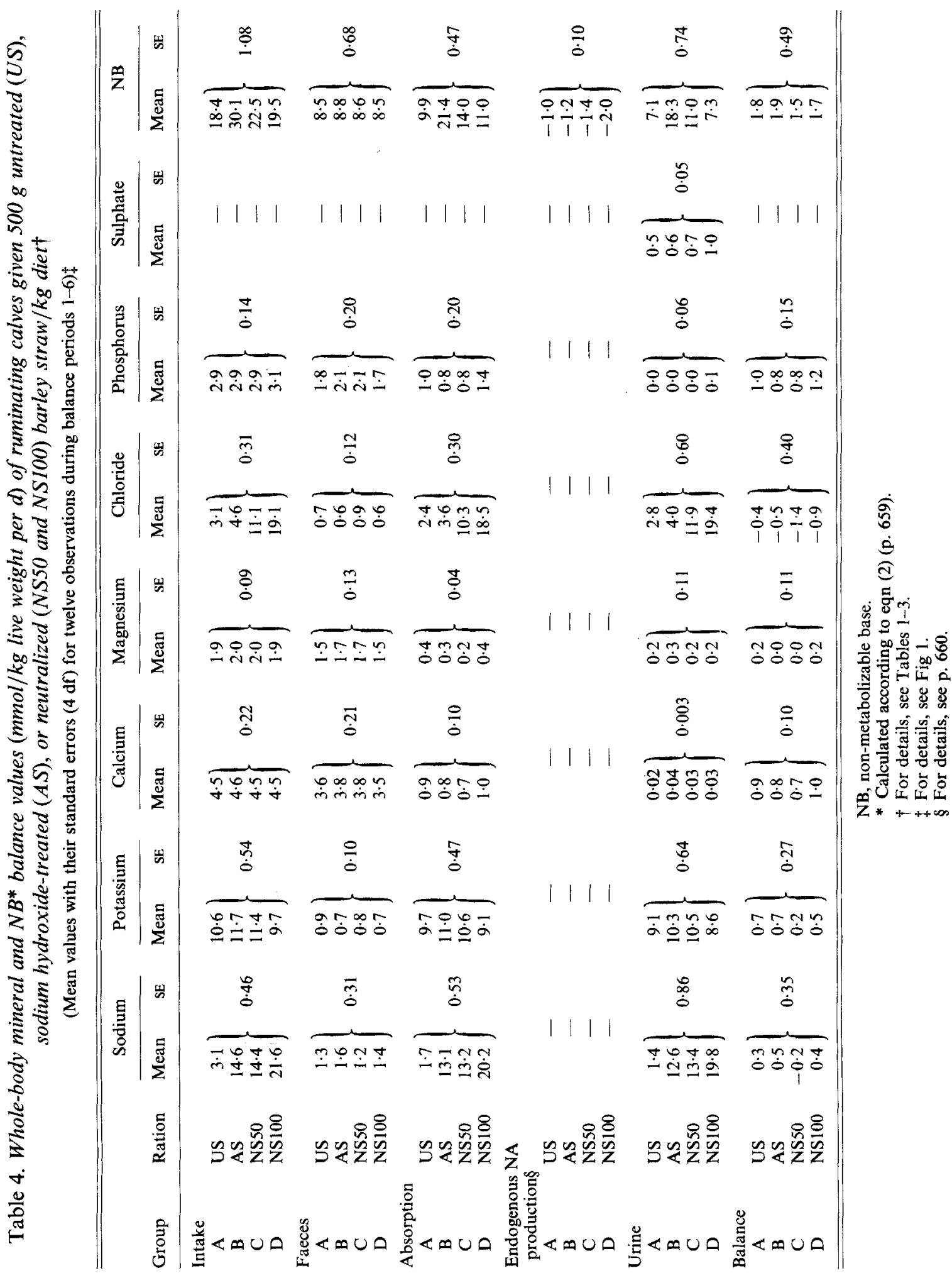


Table 5. Urinary volumes $(l / d), p H$, and concentrations of acid-base quantities and electrolytes (mmol/l) of ruminating calves given $500 \mathrm{~g}$ untreated (US), sodium hydroxide-treated $(A S)$, or neutralized (NS5O and NS100) barley straw $/ \mathrm{kg}$ diet $^{*}$

(Mean values with their standard errors ( $4 \mathrm{df}$ ) for twelve observations during balance periods $1-6) \dagger$

\begin{tabular}{|c|c|c|c|c|c|c|c|c|c|c|c|c|c|c|c|c|}
\hline \multirow[b]{2}{*}{ Grour } & \multirow[b]{2}{*}{ p Ration } & \multicolumn{2}{|c|}{ Volume } & \multicolumn{2}{|c|}{$\mathrm{pH}$} & \multicolumn{2}{|c|}{$\begin{array}{c}c \mathrm{NCA}(\mathrm{U})+ \\
{ }_{c \mathrm{NH}_{4}}{ }^{+}(\mathrm{U})\end{array}$} & \multicolumn{2}{|c|}{$c \mathrm{MA}_{\mathrm{g}}(\mathrm{U})$} & \multicolumn{2}{|c|}{$c \mathbf{N B}(\mathbf{U})$} & \multicolumn{2}{|c|}{$c \mathrm{Na}^{+}(\mathbf{U})$} & \multicolumn{2}{|c|}{$c \mathrm{~K}^{+}(\mathrm{U})$} & $c \mathrm{Cl}^{-}(\mathrm{U})$ \\
\hline & & Mean & $\mathrm{SE}$ & Mean & $S E$ & Mean & $\mathbf{S E}$ & Mean & SE & Mean & $\mathrm{SE}$ & Mean & $\mathrm{SE}$ & Mean & SE & Mean \\
\hline A & US & 6.21 & & $8 \cdot 6$ & & $-166 \cdot 1$ & & 114.01 & & $280 \cdot 3]$ & & $57 \cdot 2$ & & 367.5 & & 113.0 \\
\hline B & AS & $19 \cdot 7$ & & $8 \cdot 5$ & 0.1 & $-206 \cdot 0$ & $L_{2}$ & 39.9 & & 245.9 & & $168 \cdot 3$ & 175 & 138.5 & 16.3 & 53.6 \\
\hline $\mathrm{C}$ & NS50 & $11.4\}$ & 1.32 & $8 \cdot 4$ & 0.1 & -176.9 & $21 \cdot 0$ & 54.4 & $4 \cdot 3$ & $231 \cdot 3$ & $24 \cdot 5$ & 281.8 & 17.5 & 219.8 & $16 \cdot 3$ & 250.0 \\
\hline D & NS 100 & 16.5 & & $8 \cdot 3$ & & $-80 \cdot 1$ & & 27.2 & & 107.4 & & $285 \cdot 3$ & & $124 \cdot 3$ & & 279.7 \\
\hline
\end{tabular}

$c \mathrm{NCA}(\mathrm{U})+c \mathrm{NH}_{4}{ }^{+}(\mathrm{U})$, concentrations of titratable non-carbonic acid and ammonium in urine, determined according to Jørgensen (1957) (see p. 659); $c \mathrm{MA}_{\mathrm{g}}(\mathrm{U})$, concentration in urine of filtered metabolizable organic acid (see p. 659); $c \mathrm{NB}(\mathrm{U})$, concentration in urine of non-metabolizable base, calculated according to eqn (2) (p. 659$) ; c \mathrm{Na}^{+}(\mathrm{U}), c \mathrm{~K}^{+}(\mathrm{U})$ and $\mathrm{cCl}^{-}(\mathrm{U})$, concentrations of sodium, potassium and chloride in urine.

* For details, see Tables 1-3.

$\dagger$ For details, see Fig. 1.

(Table 6). Moreover, in all groups plasma concentrations of $\mathrm{Na}(137 \cdot 1-143 \cdot 7 \mathrm{mmol} / \mathrm{l}), \mathrm{K}$ (4.0-4.6 $\mathrm{mmol} / \mathrm{l})$ and $\mathrm{Cl}(97 \cdot 2-102.3 \mathrm{mmol} / \mathrm{l})$ remained within the normal range published by McSherry \& Grinyer (1954), irrespective of the time of blood sampling.

\section{DISCUSSION}

The main result of the present study was a demonstration of the ability of the ruminating calf to tolerate long-term alkali-straw feeding, given free access to fresh water. Thus, in all groups a normal plasma acid-base and electrolyte status was maintained and adverse effects on health or body growth were not observed. This is in agreement with previous observations in ruminating cattle given various amounts of alkali-treated roughage (Stigsen, 1975; Jackson, 1977) or dietary supplements of alkali-salt mixtures (Brouwer, 1935; Bhattacharya \& Warner, 1968).

\section{Effects of alkali-loading}

It appears from the present findings (Table 4 and Fig. 2) that the basic ration of group A provided a dietary intake of NB of about $15-18 \mathrm{mmol} / \mathrm{kg} \mathrm{LW}$ per d, approximately $50 \%$ of which was lost by faecal excretion. Apparently then, during normal body growth, the net rate of gastrointestinal NB absorption exceeds the sum of rates of endogenous $\mathrm{H}_{2} \mathrm{SO}_{4}$ production and NB retention, leaving considerable amounts of dietary NB to be excreted (mainly as potassium bicarbonate) in an alkaline urine with a $\mathrm{pH}$ value above 8 (Table 5). The positive balance of NB (1-2 mmol/ $\mathrm{kg} \mathrm{LW}$ per d) reflects the deposition of absorbed NB along with dietary mineral constituents in 'new tissue', largely the skeleton (Forbes, 1909; Shohl \& Sato, 1923; Wamberg et al. 1976b). Considering the processes of bone formation it appears that $0.92 \mathrm{mmol} \mathrm{NB}$ is required for every $1 \mathrm{mmol} \mathrm{Ca}$ deposited as crystalline hydroxyapatite $\left(\mathrm{Ca}_{3}\left(\mathrm{PO}_{4}\right)_{2}\right)_{3} . \mathrm{Ca}(\mathrm{OH})_{2}$ (Kildeberg, 1981). In the present study $\mathrm{NB}$ and $\mathrm{Ca}$ were retained at a molar ratio of about 2 and, therefore, additional amounts of NB may have been deposited as phosphates and carbonates along with $\mathrm{Ca}, \mathrm{Mg}$ and $\mathrm{Na}$ in amorphous bone mineral. Thus, as indicated by the present findings, the growing calf is in a state of 'relative hypermineralization' due to the rapid development of the skeleton. 
Table 6. Arterial blood and plasma acid-base values of ruminating calves given $500 \mathrm{~g}$ untreated (US), sodium hydroxide-treated (AS) or neutralized (NS50 and NS100) barley straw/kg diet*

(Mean values with their standard errors ( $4 \mathrm{df}$ ) for four samples per group obtained by permanent catheterization during days 4 and 5 of period 6$) \dagger$

\begin{tabular}{|c|c|c|c|c|c|c|c|c|c|c|}
\hline \multirow{2}{*}{$\begin{array}{l}\text { Time of day of blood } \\
\text { sampling (hours)... } \\
\text { Variable }\end{array}$} & \multirow[b]{2}{*}{ Group } & \multirow[b]{2}{*}{ Ration } & \multicolumn{2}{|c|}{08.00} & \multicolumn{2}{|c|}{10.00} & \multicolumn{2}{|c|}{12.30} & \multicolumn{2}{|c|}{15.00} \\
\hline & & & Mean & $\mathrm{SE}$ & Mean & $\mathrm{SE}$ & Mean & $\mathrm{SE}$ & Mean & SE \\
\hline $\mathrm{pH}$ & $\begin{array}{l}\text { A } \\
\text { B } \\
\text { C } \\
\text { D }\end{array}$ & $\begin{array}{l}\text { US } \\
\text { AS } \\
\text { NS50 } \\
\text { NS } 100\end{array}$ & $\left.\begin{array}{l}7 \cdot 45 \\
7 \cdot 46 \\
7 \cdot 44 \\
7 \cdot 46\end{array}\right\}$ & 0.04 & $\left.\begin{array}{l}7 \cdot 46 \\
7 \cdot 47 \\
7 \cdot 44 \\
7 \cdot 46\end{array}\right\}$ & 0.03 & $\left.\begin{array}{l}7 \cdot 44 \\
7 \cdot 46 \\
7.43 \\
7 \cdot 45\end{array}\right\}$ & 0.02 & $\left.\begin{array}{l}7 \cdot 44 \\
7 \cdot 48 \\
7 \cdot 45 \\
7 \cdot 47\end{array}\right\}$ & 0.05 \\
\hline $\begin{array}{l}\text { Carbon dioxide } \\
\text { potential }(\mathrm{mmHg})\end{array}$ & $\begin{array}{l}\text { A } \\
\text { B } \\
\text { C } \\
\text { D }\end{array}$ & $\begin{array}{l}\text { US } \\
\text { AS } \\
\text { NS50 } \\
\text { NS100 }\end{array}$ & $\left.\begin{array}{l}35 \cdot 0 \\
31 \cdot 8 \\
34 \cdot 4 \\
33 \cdot 5\end{array}\right\}$ & $2 \cdot 1$ & $\left.\begin{array}{l}35 \cdot 2 \\
33 \cdot 3 \\
34 \cdot 2 \\
33 \cdot 1\end{array}\right\}$ & $3 \cdot 6$ & $\left.\begin{array}{l}35 \cdot 8 \\
32 \cdot 8 \\
34 \cdot 7 \\
33 \cdot 1\end{array}\right\}$ & 3.9 & $\left.\begin{array}{l}35 \cdot 1 \\
31 \cdot 2 \\
35 \cdot 4 \\
31 \cdot 7\end{array}\right\}$ & 4.9 \\
\hline$c \mathrm{BE}(\mathrm{P})(\mathrm{mmol} / \mathrm{l})$ & $\begin{array}{l}\text { A } \\
\text { B } \\
\text { C } \\
\text { D }\end{array}$ & $\begin{array}{l}\text { US } \\
\text { AS } \\
\text { NS50 } \\
\text { NS100 }\end{array}$ & $\left.\begin{array}{r}0.7 \\
-0.6 \\
-0.3 \\
0.1\end{array}\right\}$ & $1 \cdot 0$ & $\left.\begin{array}{r}1.5 \\
-0.3 \\
-0.6 \\
0.1\end{array}\right\}$ & 0.7 & $\left.\begin{array}{r}0.7 \\
-0.2 \\
-0.8 \\
-0.7\end{array}\right\}$ & $1 \cdot 1$ & $\left.\begin{array}{r}-0.1 \\
-0.1 \\
0.4 \\
0.1\end{array}\right\}$ & $1 \cdot 2$ \\
\hline$c \mathrm{NB}(\mathrm{P})(\mathrm{mmol} / \mathrm{l})$ & $\begin{array}{l}\text { A } \\
\text { B } \\
\text { C } \\
\text { D }\end{array}$ & $\begin{array}{l}\text { US } \\
\text { AS } \\
\text { NS50 } \\
\text { NS } 100\end{array}$ & $\left.\begin{array}{l}43 \cdot 1 \\
45 \cdot 9 \\
44 \cdot 3 \\
41 \cdot 6\end{array}\right\}$ & $4 \cdot 8$ & $\left.\begin{array}{l}47 \cdot 2 \\
42 \cdot 9 \\
42 \cdot 9 \\
45 \cdot 4\end{array}\right\}$ & $3 \cdot 5$ & $\left.\begin{array}{l}47 \cdot 2 \\
46 \cdot 3 \\
42 \cdot 7 \\
40 \cdot 1\end{array}\right\}$ & $3 \cdot 0$ & $\left.\begin{array}{l}45 \cdot 1 \\
44 \cdot 6 \\
41 \cdot 3 \\
42 \cdot 0\end{array}\right\}$ & $4 \cdot 2$ \\
\hline$c \mathrm{MA}(\mathrm{P})(\mathrm{mmol} / \mathrm{l})$ & $\begin{array}{l}\text { A } \\
\text { B } \\
\text { C } \\
\text { D }\end{array}$ & $\begin{array}{l}\text { US } \\
\text { AS } \\
\text { NS50 } \\
\text { NS } 100\end{array}$ & $\left.\begin{array}{l}18 \cdot 4 \\
22 \cdot 0 \\
20 \cdot 6 . \\
17 \cdot 3\end{array}\right\}$ & $5 \cdot 9$ & $\left.\begin{array}{l}21 \cdot 6 \\
18 \cdot 2 \\
18 \cdot 3 \\
21 \cdot 4\end{array}\right\}$ & $3 \cdot 3$ & $\left.\begin{array}{l}22 \cdot 5 \\
22 \cdot 5 \\
19 \cdot 5 \\
16 \cdot 6\end{array}\right\}$ & $3 \cdot 3$ & $\left.\begin{array}{l}21 \cdot 1 \\
20 \cdot 7 \\
16 \cdot 9 \\
17 \cdot 9\end{array}\right\}$ & $4 \cdot 8$ \\
\hline
\end{tabular}

$c \mathrm{BE}(\mathrm{P})$, concentration of plasma 'base excess' (Siggaard-Andersen, 1974); $c \mathrm{NB}(\mathrm{P})$ and $c \mathrm{MA}(\mathrm{P})$, concentrations in plasma of non-metabolizable base and metabolizable organic acid, calculated according to eqns (2) and (4) respectively (see p. 659).

In all cases the difference observed between dietary groups or time of blood sampling were not statistically significant $(P>0.05)$ (see p. 658).

* For details, see Tables 1-3.

$\dagger$ For details, see p. 658 .

In the case of alkali-straw feeding it appears from the present findings that the amount of dietary NB ingested by the ruminating animal may be increased to about $30 \mathrm{mmol} / \mathrm{kg}$ LW per d without significant changes in faecal NB excretion (Table 4) or in blood and plasma acid-base status (Table 6), the amount of absorbed dietary NB being quantitatively excreted by the kidneys. In group B, urinary NB concentration was slightly lower than the apparent maximum value of about $300 \mathrm{mmol} / 1$ (Brouwer, 1935) and the excess load of NB was excreted by means of a threefold increase in urinary volume, accounted for by a corresponding increase in water intake (see p. 660). In comparison, the animals of group D absorbed an extra load of about $18 \mathrm{mmol} \mathrm{NaCl} / \mathrm{kg} \mathrm{LW}$ per d and excreted it in a relatively less increased volume of urine (Table 5). In these animals, however, the concurrent rise in water intake (Table 1) accounted for only $50 \%$ of the increase in urinary volume. Since the animals behaved normally, gained weight and did not develop acidosis, it seems unlikely that dehydration or decreased perspiratory or respiratory water loss could have contributed to the increase in urinary volume. Possibly, therefore, additional water was provided by a shift in water excretion from faeces to urine (see p. 660). Finally, in spite of 'alkalinization' or $\mathrm{Na}$ and $\mathrm{Cl}$ loading of the diet, or both, the mean rates of mineral 


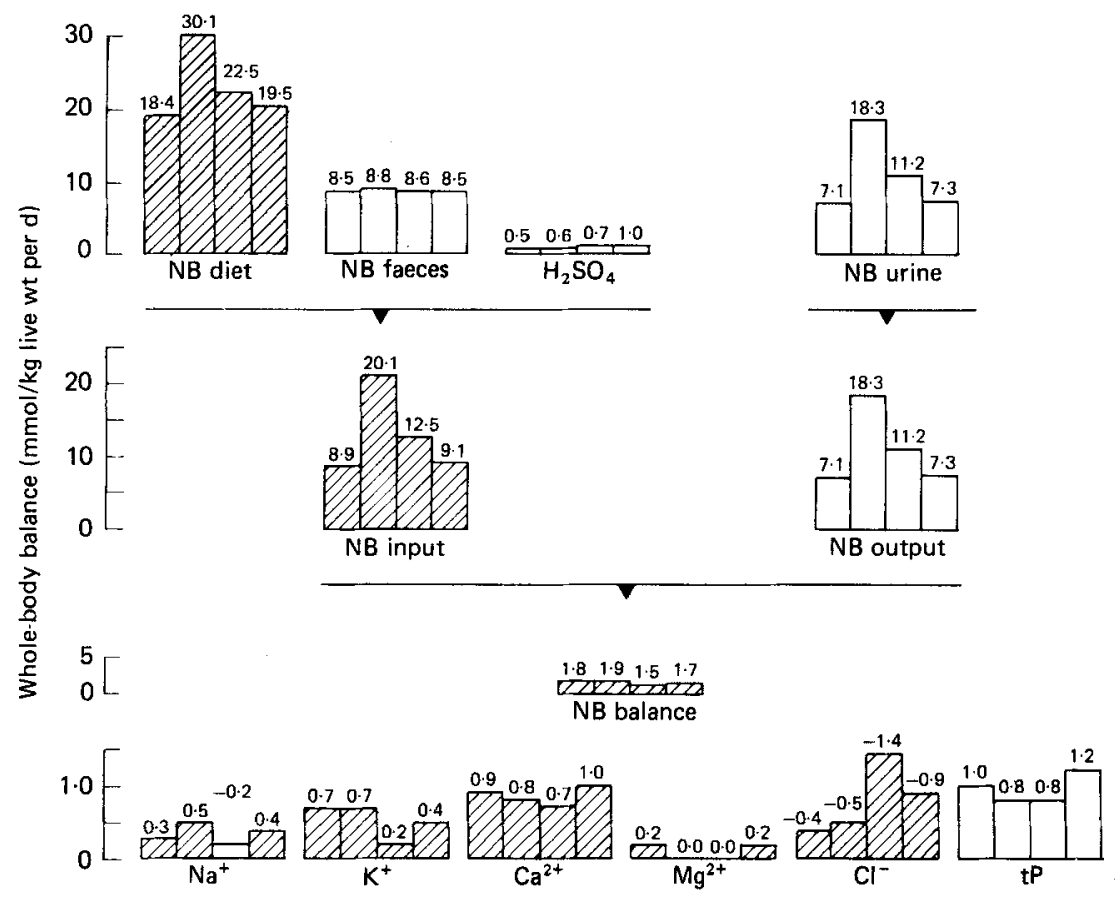

Fig. 2. Histograms representing the components of whole-body balance of non-metabolizable base (NB) in four groups (A-D) of ruminating calves given untreated (US), alkali-treated (AS) or neutralized (NS50 and NS100) barley straw rations (for details of rations, see Tables 2 and 3). The groups of four columns, from left to right, represent the values obtained in groups A, B, C and D respectively. Gains of NB (梮), gains of non-metabolizable acid (NA) ( $\square$ ) (see p. 660). tP, Total P.

retention obtained in the present study were almost identical in the four groups, and within the range of the values reported in the literature (Ellenberger et al. 1950; Duncan, 1958; Singh \& Jackson, 1971).

The present findings are in accordance with the observation by Kellaway et al. (1977) that supplementation of the ration with $\mathrm{NaHCO}_{3}$ up to about $700 \mathrm{mmol} / \mathrm{kg} \mathrm{DM}$ is well tolerated by young non-ruminating calves, whereas dietary loading above this level produces frank non-carbonic alkalosis. In a similar study in young growing rats given dietary loads of $\mathrm{NaHCO}_{3}$ or sodium citrate (about $50 \mathrm{mmol} / \mathrm{kg} \mathrm{LW}$ per d), we observed a remarkable increase in $\mathrm{Na}$ and $\mathrm{NB}$ retention (Wamberg et al. 1978), indicating a relative hypermineralization of the skeleton, without any apparent effects on blood acid-base status or rate of body growth. Moreover, according to Brouwer (1935), milk cows may be given dietary alkali loads up to about $30 \mathrm{mmol} / \mathrm{kg}$ per d for $54 \mathrm{~d}$ without unfavourable consequences.

In principle, renal control of the acid-base status of the extracellular fluid compartment is maintained by continuous removal of NB by glomerular filtration and controlled replacement by tubular 'reabsorption' of $\mathrm{NaOH}$. In any dynamic steady-state (including constant extracellular volume) the concentration of NB in extracellular water (E) is given by:

$$
c \mathrm{NB}(\mathrm{E})=\frac{\dot{n} \mathrm{NB}(\mathrm{t})+\dot{n} \mathrm{NB}(\mathrm{i})}{\mathrm{GFR}},
$$

where $\dot{n} \mathrm{NB}(\mathrm{t})$ is the rate of tubular regeneration ('reabsorption') of filtered NB, equal to the rate of tubular secretion of hydrogen ion; $\dot{n} \mathrm{NB}(\mathrm{i})$ is the net rate of gain of $\mathrm{NB}$ by the 
extracellular compartment by all non-renal processes; GFR is the rate of glomerular volume filtration (Kildeberg, 1981). In all groups of the present study the mean concentration of NB in plasma was approximately $44 \mathrm{mmol} / 1$ (Table 6), similar to the value that can be calculated from the values of McSherry \& Grinyer (1954). In the alkali-loaded animals of group B, the mean rate of renal NB excretion was $18.3 \mathrm{mmol} / \mathrm{kg} \mathrm{LW}$ per $\mathrm{d}$ and taking the average rate of glomerular filtration to be about $3.71 / \mathrm{kg} \mathrm{LW}$ per d (Anderson \& Mixner, 1960), it appears that the fractional excretion of filtered NB in this group may have been about $12 \%$. This value, which is almost identical to the value of $13 \%$ observed by Voigt \& Piatkowski (1974) in alkali-straw-fed cows and similar to the value of $15 \%$ obtained by us in $\mathrm{NaHCO}_{3}$-loaded growing rats (Wamberg et al. 1978), illustrates the capacity of the mammalian kidney to maintain a normal extracellular electrolyte and acid-base status during Na and NB loading.

\section{Effects of neutralization}

Considering the effects of neutralization of the rations with $\mathrm{HCl}$ it appears that the findings of the present study agree well with several reports of the ability of mature ruminants to excrete massive dietary loads of $\mathrm{Na}$ and $\mathrm{Cl}$, provided adequate water is available. Thus, Meyer et al. (1955) observed a $50 \%$ increase in water intake by steers given $33 \mathrm{mmol} \mathrm{NaCl} / \mathrm{kg}$ LW per d for $84 \mathrm{~d}$ without any detrimental effects. Similarly, in steers given up to $18 \mathrm{mmol} \mathrm{NaCl} / \mathrm{kg} \mathrm{LW}$ per d, Nelson et al. (1955) found a threefold increase in daily urinary volume and a small but significant increase in whole-body balances of $\mathrm{Na}$ and $\mathrm{Cl}$, whereas the mean rate of $\mathrm{N}$ retention remained unchanged. Water supplies containing $10 \mathrm{~g} \mathrm{NaCl} / 1$ (about $36 \mathrm{mmol} \mathrm{NaCl} / \mathrm{kg} \mathrm{LW}$ per d) are well tolerated by young heifers (Weeth \& Haverland, 1961) whereas larger loads depress feed consumption and growth rate. In heifers given $15 \mathrm{~g} \mathrm{NaCl} / 1$ drinking water, Weeth \& Lesperance (1965) observed pronounced hypernatraemia, increased plasma osmolality and a tenfold increase in daily urinary $\mathrm{Na}$ excretion without significant changes in urinary osmolality.

Even in simple-stomached animals it appears to be difficult to induce salt poisoning by dietary $\mathrm{NaCl}$ loading, due partly to impalatability (Medway \& Kare, 1959; Gyrd-Hansen, 1972) but mainly to the renal capacity for excretion of dietary alkali-salts by the process of glomerular filtration (Potter, 1961, 1963; Mason \& Scott, 1974; Kildeberg, 1981).

Dr Grete Thorbek and Dr Lise Neergaard are gratefully acknowledged for continual encouragement and support. The authors are grateful to Professor P. Kildeberg for critical reading of the manuscript and to Bent Jørgensen for statistical guidance and help. We also wish to thank H. B. Kelmann Hansen, Anette Linde, Anne-Grethe Lorenzen, Vibeke Nielsen, Inge Roth and Inge Staffelt for excellent technical assistance. The study was supported by grant no. 513-5133 from the Danish Agricultural and Veterinary Research Council.

\section{REFERENCES}

Anderson, R. R. \& Mixner, J. P. (1960). Journal of Dairy Science 43, 1476-1479.

Baker, R. J. \& Nelder, J. A. (1978). The GLIM System: Generalised Linear Interactive Modelling, Release 3. London: Royal Statistical Society.

Bhattacharya, A. N. \& Warner, R. G. (1968). Journal of Animal Science 27, 1418-1425.

Brouwer, E. (1935). Tierernährung 7, 463-495.

Coombe, J. B., Dinius, D. A. \& Wheeler, W. E. (1979). Journal of Animal Science 49, 169-176.

Dobson, A. (1980). In Scientific Foundations of Veterinary Medicine, pp. 112-125. [A. T. Phillipson, L. W. Hall and W. R. Pritchard, editors]. London: Heinemann Medical Books Ltd.

Duncan, D. L. (1958). Nutrition Abstracts and Reviews 28, 695-715.

Ellenberger, H. B., Newlander, J. A. \& Jones, C. H. (1950). Vermont Agricultural Experiment Station Bulletin no. $558, \mathrm{pp} .1-66$. 
Engel, K. \& Kildeberg, P. (1977). Scandinavian Journal of Clinical \& Laboratory Investigation 37, Suppl. $146,21-26$. Forbes, E. B. (1909). Ohio Agricultural Experiment Station Bulletin no. 207, pp. 23-52.

Friis Kristensen, V., Andersen, P. E., Stigsen, P., Vestergaard Thomsen, K., Andersen, H. R., Sørensen, M., Ali, C. S., Mason, V. C., Rexen, F., Israelsen, M. \& Wolstrup, J. (1978). National Institute of Animal Science Report no. 464, pp. 1-218.

Gyrd-Hansen, N. (1972). Studies on salt poisoning in pigs. PhD Thesis, The Royal Veterinary and Agricultural University, Copenhagen.

Hills, A. G. (1973). Acid-Base Balance. Chemistry, Physiology, Pathophysiology. Baltimore: Williams \& Wilkins Co.

Jackson, M. G. (1977). Animal Feed Science and Technology 2, 105-130.

Jørgensen, K. (1957). Scandinavian Journal of Clinical \& Laboratory Investigation 9, $287-291$.

Kellaway, R. C., Thomson, D. J., Beever, D. E. \& Osbourn, D. F. (1977). Journal of Agricultural Science 88, 1-9.

Kildeberg, P. (1981). Quantitative Acid-Base Physiology. System Physiology and Pathophysiology of Renal, Gastrointestinal, and Skeletal Acid-Base Metabolism. Odense: Odense University Press. New York and Tokyo: Igaku-Shoin Medical Publishers.

Kildeberg, P. (1983). Scandinavian Journal of Clinical \& Laboratory Investigation 43, 103-109.

Kildeberg, P. \& Winters, R. W. (1978). In Advances in Pediatrics vol. 25, pp. 349-381. [L. A. Barnes, editor]. New York: Year Book Medical Publishers Inc.

McSherry, B. J. \& Grinyer, I. (1954). American Journal of Veterinary Research 15, 509-510.

Mason, G. D. \& Scott, D. (1974). Quarterly Journal of Experimental Physiology 59, 103-112.

Medway, W. \& Kare, M. R. (1959). Cornell Veterinarian 49, 241-251.

Meyer, J. H., Weir, W. C., Ittner, N. R. \& Smith, J. D. (1955). Journal of Animal Science 14, 412-418.

Nelson, A. B., MacVicar, R. W., Archer, Wm. Jr \& Meiske, J. C.(1955). Journal of Animal Science 14, 825-830.

Oloade, B. G. \& Mowat, D. N. (1975). Journal of Animal Science 40, 351-357.

Potter, B. J. (1961). Australian Journal of Agricultural Research 12, 440-445.

Potter, B. J. (1963). Australian Journal of Agricultural Research 14, 518-528.

Rexen, F. \& Vestergaard Thomsen, K. (1976). Animal Feed Science and Technology 1, 73-83.

Saxena, S. K., Otterby, D. E., Donker, J. D. \& Good, A. L. (1971). Journal of Animal Science 33, 485-490.

Shohl, A. T. \& Sato, A. (1923). Journal of Biological Chemistry 58, 235-255.

Siggaard-Andersen, O. (1974). The Acid-Base Status of the Blood, 4th revised ed. Copenhagen: Munksgaard. Baltimore: Williams \& Wilkins Co.

Singh, M. \& Jackson, M. G. (1971). Journal of Agricultural Science, Cambridge 77, 5-10.

Sriskandarajah, N. \& Kellaway, R. C. (1984). British Journal of Nutrition 51, 289-296.

Stigsen, P. (1975). Kulhydratkildens og neutralisationens betydning for udnyttelse af natriumhydroxydbehandlet halm hos malkekøer. PhD Thesis, The Royal Veterinary and Agricultural University, Copenhagen.

Thorbek, G. (1980). National Institute of Animal Science Report no. 498 (Denmark), pp. 1-104 (in English).

Voigt, J. \& Piatkowski, B. (1974). Archiv für Tierernährung 24, 589-600.

Wamberg, S., Engel, K. \& Kildeberg, P. (1983). Scandinavian Journal of Clinical \& Laboratory Investigation 43, $73-83$.

Wamberg, S., Hansen, A. C., Engel, K. \& Kildeberg P. (1978). Biology of the Neonate 34, 24-31.

Wamberg, S., Kildeberg, P. \& Engel, K. (1976a). Biology of the Neonate 28, 160-170.

Wamberg, S., Kildeberg, P. \& Engel, K. (1976 b). Biology of the Neonate 28, 171-190.

Weeth, H. J. \& Haverland, L. H. (1961). Journal of Animal Science 20, 518-521.

Weeth, H. J. \& Lesperance, A. L. (1965). Journal of Animal Science 24, 441-447. 